\title{
ARTICLE \\ Soil Seed Banks in Two Environments of Forest Restoration Post Bauxite Mining: Native Tree Plantation and Natural Regeneration
}

\author{
Sebastião Venâncio Martins * Wesley da Silva Fonseca Luiz Henrique Elias Cosimo Diego Balestrin \\ Forest Restoration Laboratory, Department of Forest Engineering, Universidade Federal de Viçosa, Viçosa, Minas \\ Gerais, Brazil
}

\section{ARTICLE INFO}

Article history

Received: 30 November 2020

Accepted: 31 December 2020

Published Online: 30 March 2021

\section{Keywords:}

Ecological restoration

Bioindicators

Floristic similarity

Diversity

Forest ecology

\section{ABSTRACT}

The objective of this study was to compare the soil seed bank in an area under natural regeneration (F1) and another reforested through seedling planting (F2), seven years after bauxite mining, in Southeast, Brazil. In each area, 10 sampling points were randomly distributed, using three samples of topsoil to represent each point. The samples were transported to a shade house and evaluated for six months, where emerging individuals were identified every two weeks. Floristic similarity was evaluated with cluster analysis based on the Jaccard index (SJ). Species richness and abundance of individuals were compared using Student's t test. In F1, 2,114.94 propagules m-2 were registered, belonging to 51 species and 24 botanical families, Shannon-Wiener diversity index $\mathrm{H}^{\prime}=2.770$ and Pielou evenness index $\mathrm{J}^{\prime}=0.705$. In $\mathrm{F} 2,1,168.62$ propagules $\mathrm{m}-2$ were registered, belonging to 42 species and 22 families, $H^{\prime}=2.618$ and $J^{\prime}=0.700$. The (SJ) between F1 and F2 was 0.61 , indicating a high similarity. The results showed high density of propagules, good diversity and absence of ecological dominance. The high number of individuals and diversity of tree species with zoochoric dispersion found in the areas indicates that both natural regeneration and reforestation were efficient in the ecological restoration of bauxite mined areas.

development ${ }^{[2]}$.

However, bauxite mining causes punctual impacts due to the suppression of vegetation and the removal of superficial layers of soil, which, despite not occupying large territorial extensions (such as agriculture and livestock), can cause imbalances in the environment ${ }^{[3,4]}$.

Therefore, choosing efficient restoration techniques is essential to reduce the environmental impacts in these areas, to optimize the amount of resources spent in this process, as well as to accelerate the vegetal cover and to reestablish ecological functions in these environments ${ }^{[5]}$.

*Corresponding Author:

Sebastião Venâncio Martins,

Forest Restoration Laboratory, Department of Forest Engineering, Universidade Federal de Viçosa, Viçosa, Minas Gerais, Brazil; Email:venancio@ufv.br 
In addition to conserving the existing diversity, forest restoration is able to minimize erosive processes and increase the carbon stock, which can contribute to climate change mitigation ${ }^{[6]}$.

In this sense, the effectiveness of a forest restoration project must be assessed using evaluation and monitoring indicators ${ }^{[7]}$, in regular time periods, using phytosociological studies. Such studies are subsidies for understanding the structure and dynamics of forest formations, as well as the arrangements, ecological processes, functions and interdependence of ecosystem components, in addition to enabling a comparison between the restored area and the reference ecosystem ${ }^{[8]}$.

Through these environmental indicators, it is possible to define the current status of the project, identify flaws in the restoration process and correct the trajectory ${ }^{[7]}$, reducing costs to achieve the objectives and goals defined in these projects. It is also possible to determine the stage at which the restored area shows signs of becoming self-sustainable over time and fulfilling its role in the conservation of local biodiversity, dispensing management interventions, in addition to ensuring a constant improvement of ecological restoration ${ }^{[5]}$.

The most frequently used forest restoration assessment indicators are vegetative indicators such as: natural regeneration, seed rain, canopy opening, litter production and decomposition, planted seedling growth and survival, nutrient cycling and soil seed bank ${ }^{[5,9]}$. These vegetative indicators have the advantage of being relatively easy to quantify when compared with other biological indicators ${ }^{[8]}$.

The soil seed bank is composed of a stock of viable seeds, present in the soil or in the litter, which can germinate soon after their dispersion or persist in a dormant state until they receive favorable conditions for germination ${ }^{[10,11,12]}$. According to Calegari et al. ${ }^{[13]}$, these seeds can be autochthonous, that is, originating from species in the area itself or allochthonous, coming from species from adjacent areas.

The study of the floristic composition, dynamics and density of the soil seed bank is important to evaluate conservation status and the potential for restoration of forest ecosystems ${ }^{[12,13,14]}$. This forest component is closely linked to the establishment of plant populations, the maintenance of species diversity, the establishment of ecological groups and the potential for natural regeneration of an ecosystem in the face of possible disturbances, that is, its resilience ${ }^{[13,15]}$. In this way, the soil seed bank stands out as a good bioindicator in assessing the potential success of forest restoration projects.

Thus, the objective of this study was to evaluate and characterize the soil seed bank through a comparative study in two adjacent areas under restoration: an area under natural regeneration (F1) and another reforested by planting seedling (F2), after bauxite mining in the Zona da Mata region of Minas Gerais State, Brazil.

\section{Materials and Methods}

\subsection{Characterization of the Study Site}

The study was conducted in the municipality of São Sebastião da Vargem Alegre (Figure 1), located in the region denominated Zona da Mata, in Southeastern Minas Gerais State, Brazil, in two adjacent areas: Forest 1 (F1) forest under restoration by natural regeneration (extreme location points are $21^{\circ} 2^{\prime} 0.06^{\prime \prime} \mathrm{S}, 42^{\circ} 34^{\prime} 58,55^{\prime \prime} \mathrm{W}$ and $21^{\circ} 1^{\prime} 57.64$ " S, $42^{\circ} 35^{\prime} 2.24^{\prime \prime} \mathrm{W}$ ), with a surface area of 0.5 hectares and Forest 2 (F2) - forest under restoration by planting of seedlings of native tree species $\left(21^{\circ} 11^{\prime} 57.50^{\prime \prime}\right.$ $\mathrm{S}, 42^{\circ} 35^{\prime} 2.42^{\prime} \mathrm{W}$ and $21^{\circ} 1^{\prime} 55.79^{\prime \prime} \mathrm{S}, 42^{\circ} 35^{\prime} 2.81^{\prime} \mathrm{W}$ ), with a surface area of 0.15 hectares.

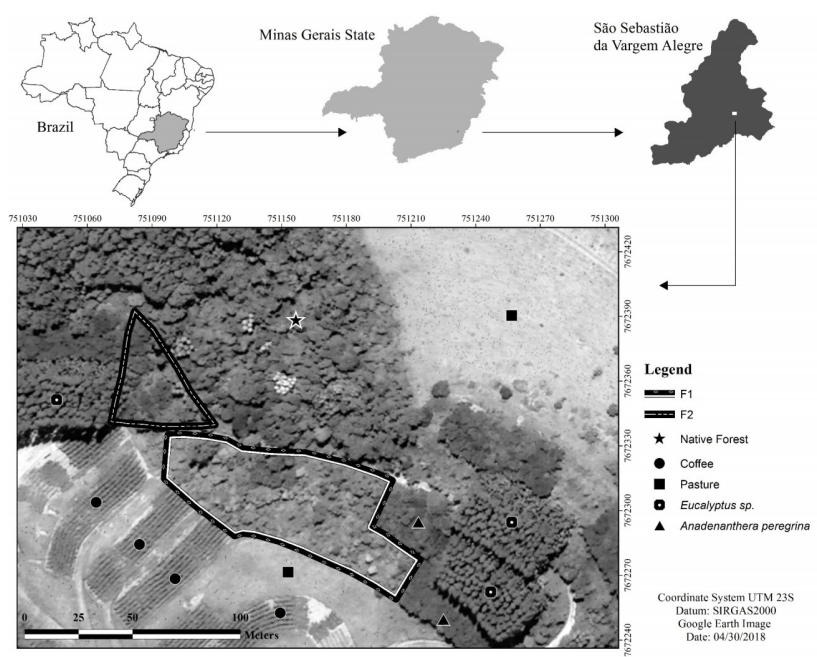

Figure 1. Study site, São Sebastião da Vargem Alegre County, Minas Gerais State, Brazil.

According to the Köppen ${ }^{[16]}$ classification, the region's climate is type Cwa, humid temperate with hot summer and dry winter. The average temperature is $23.5^{\circ} \mathrm{C}$, ranging from $18-31^{\circ} \mathrm{C}$, with an average rainfall of $1564 \mathrm{~mm}^{[17]}$.

The region has altitudes between 670 and $780 \mathrm{~m}$ and rugged relief, ranging from heavily undulating to mountainous. According to the Brazilian Soil Classification System ${ }^{[18]}$, typical dystrophic Red-Yellow Latosol soils predominate in the region, with typical vegetation classified as Semideciduous Seasonal Montane Forest ${ }^{[19]}$.

Historically, the studied areas were used for livestock and coffee farming. Between 2009 and 2010, bauxite mining was carried out. After the extraction of the ore, 
topographic reconformation was performed in both areas, as well as the transposition of a $50 \mathrm{~cm}$ layer of topsoil that had been removed and stored before mining. Subsequently, the soil was prepared with subsoiling and the formation of level terraces ${ }^{[20]}$.

After the actions of soil preparation and fencing of the whole area, one of the areas was maintained without new interferences to assess the potential for natural regeneration and another received the planting of seedlings of tree species native to the Brazilian Atlantic Forest, as it is normally done in the mined areas of the region (Table 1). In this way, both areas have the same age of restoration and the evaluation of the seed bank occurred 7 years after mining and the application of reconformation and soil preparation techniques.

Table 1. List of tree species used in the planting of F2 (forest under restoration by the planting of native tree species).

\begin{tabular}{|c|c|c|c|}
\hline $\begin{array}{l}\text { Botanical } \\
\text { family }\end{array}$ & Species & $\mathrm{SC}$ & DS \\
\hline Annonaceae & Annona squamosa $\mathrm{L}$. & ES & Zoo \\
\hline Bignoniaceae & $\begin{array}{l}\text { Tabebuia chrysotrichia (Mart. Ex DC.) } \\
\text { Standl. }\end{array}$ & LS & Ane \\
\hline \multirow[t]{7}{*}{ Fabaceae } & Apuleia leiocarpa (Vogel) JFMacbr. & LS & Ane \\
\hline & $\begin{array}{l}\text { Hymenaea coubaril var. stilbocarpa (Hay- } \\
\text { ne) Lee \& Langenh. }\end{array}$ & LS & Zoo \\
\hline & $\begin{array}{c}\text { Paubrasilia echinata (Lam.) Gagnon, } \\
\text { H.C.Lima \& G.P.Lewis }\end{array}$ & LS & Auto \\
\hline & Anadenanthera peregrina (L.) Speg. & $\mathrm{P}$ & Ane \\
\hline & Inga edulis Mart. & ES & Zoo \\
\hline & Piptadenia gonoacantha (Mart.) JFMacbr. & ES & Auto \\
\hline & $\begin{array}{c}\text { Enterolobium contortisiliquum (Vell.) } \\
\text { Morong }\end{array}$ & $\mathrm{P}$ & Zoo \\
\hline Lecitidaceae & Lecythis sp & $\mathrm{Nc}$ & $\mathrm{Nc}$ \\
\hline Malvaceae & Ceiba speciosa (A. St.-Hil.) Ravena & LS & Ane \\
\hline Meliaceae & Trichilia $s p$ & $\mathrm{Nc}$ & $\mathrm{Nc}$ \\
\hline Moraceae & Ficus insipida Willd. & ES & Zoo \\
\hline Peraceae & Pera glabrata (Schott) Poepp. ex Baill. & ES & Zoo \\
\hline \multirow[t]{2}{*}{ Sapindaceae } & Cupania oblongifolia Mart. & $\mathrm{P}$ & Zoo \\
\hline & Sapindus saponaria $L$. & LS & Auto \\
\hline
\end{tabular}

SC: Successional category $(P=$ Pioneer, $E S=$ Early secondary, $L S=$ Late secondary); DS: Dispersal syndrome (Ane $=$ anemochory, Zoo $=$ zoochory, Auto $=$ autochory); $N c=$ Not Classified

At the time the seed bank was collected, F1 presented sparse tree individuals with an average of $3 \mathrm{~m}$ in height, presence of patches of invasive grasses, low canopy coverage and presence of individuals naturally regenerated, in several stages of development ${ }^{[20]}$. On the other hand, in F2, arboreal individuals that were planted had an average height of $8 \mathrm{~m}$, greater canopy coverage and few regenerating individuals in the understory layer. Around these areas under restoration there are coffee plantations, pastures, planted forests, areas of mineral exploration, areas in process of restoration with different ages and preserved forest fragments (Figure 1).

\subsection{Field Procedures}

The collecting of samples from the soil seed bank was carried out with the selection of 10 random sampling points in each of the forests (F1 and F2), covering the entire area in the most representative way possible and observing the minimum distance of $10 \mathrm{~m}$ from the points to the edge. At each point, a $45 \times 29 \mathrm{~cm}\left(1,305 \mathrm{~cm}^{2}\right)$ frame was used to collect three samples of topsoil to a depth of $5.0 \mathrm{~cm}$, disregarding the hard-top litter (vegetation remains, such as leaves, branches and stems), totaling 60 samples (30 in each area).

The samples from the soil seed bank were transported to the shade house of the Research Nursery of the Federal University of Viçosa, where they were transferred to plastic trays $(0.45 \times 0.29 \times 0.08 \mathrm{~m})$, with holes in the bottom for draining water excess and isolated from possible contamination by external propagules using a polyethylene screen with $50 \%$ shading. Four trays with sterile sand were placed on the bench with the purpose of controlling external contamination. The soil samples were under programmed sprinkler irrigation (four daily irrigations lasting three minutes each) for a six-month period. During this time, all emerged individuals were registered and identified through evaluation every two weeks.

\subsection{Species Classification}

The species nomenclature followed the Angiosperm Phylogeny Group - APG IV ${ }^{[21]}$, using the database of The Plant List website ${ }^{[22]}$. The species sampled in the soil seed bank were classified into succession classes, according to the criteria proposed by Budowski ${ }^{[23]}$ and adapted by Gandolfi et al. ${ }^{[24]}$ for Brazilian semi-deciduous forests, being: pioneer (P), early secondary (ES), late secondary (LS) and not classified $(\mathrm{Nc})$. They were also classified in terms of propagules dispersal syndromes as: zoochoric (Zoo), anemochoric (Ane) and autochoric (Auto) ${ }^{[25]}$. In addition, the species were also classified according to their origin as native $(\mathrm{N})$ and exotic $(\mathrm{E})$ and according to their life form as herb $(\mathrm{H})$, shrub $(\mathrm{S})$, tree $(\mathrm{T})$ and vine $(\mathrm{V})$. 


\subsection{Phytosociological and Statistical Analysis}

Phytosociological parameters like relative density (RD) and relative frequency (RF) were calculated according to Mueller-Dombois and Ellenberg ${ }^{[26]}$. The Shannon-Wiener diversity index $\left(\mathrm{H}^{\prime}\right)^{[27]}$ and the Pielou evenness index $\left(\mathrm{J}^{\prime}\right)^{[28]}$ were also calculated using the FITOPAC 2.1 software $^{[29]}$.

In F1 and F2, the mean species richness and the mean abundance of individuals, were compared using Student's $\mathrm{t}$ test for independent samples at a $5 \%$ significance level $(\mathrm{p}<0.05)$ and the Jaccard index was chosen to measure floristic similarity.

In addition, the floristic similarity between the seed banks of the areas under restoration was analyzed using the clustering technique. The cluster analysis was based on the Jaccard similarity index (SJ), using a data matrix of presence and absence of species. A dendrogram was produced using the UPGMA (Unweighted Pair Group Method with Arithmetic Mean) clustering method, to identify the spatial distribution and species behavior patterns in the two communities. These analyzes were performed using statistics in $\mathrm{R}$ version 3.5.1 and the Vegan package ${ }^{[30]}$.

\section{Results}

In the soil seed bank of the forest under restoration by natural regeneration (F1), 8,280 emerged individuals were recorded $\left(2,114.94\right.$ propagules $\left.\mathrm{m}^{-2}\right)$, belonging to 51 species and 24 botanical families (Table 2), with $\left(\mathrm{H}^{\prime}\right)=2.770$ and $(\mathrm{J})=0.705$. In the forest where seedling planting was used (F2), 4,172 emerged individuals were recorded $\left(1,168.62\right.$ propagules $\left.\mathrm{m}^{-2}\right)$, belonging to 42 species and 22 botanical families, with $\mathrm{H}^{\prime}=2.618$ and $\mathrm{J}^{\prime}=0.700$. In the control trays, with sterilized sand, there was no seedling emergence, showing the non-contamination of the experiment by seeds coming from nearby sources.

In F1, the families Phyllanthaceae (24.17\%), Asteraceae (21.27\%), Amaranthaceae (10.36\%), Oxalidaceae $(8.35 \%)$, Poaceae (6.69) presented the highest RD, totaling $70.8 \%$ of emerged individuals. On the other hand, the families with the highest RD in F2 were Asteraceae (24.93\%), Solanaceae (20.78\%), Phyllanthaceae (13.28\%), Amaranthaceae (15.2\%) and Rosaceae (7.19\%), totaling $98.62 \%$ of the individuals.

The five most abundant species in F1 were: Phyllanthus tenellus Roxb with 2001 individuals, Ageratum conyzoides L. (1216), Amaranthus deflexus L. (858), Oxalis corniculata L. (691) and Trema micrantha (L.) Blume (397). In addition to Trema micranta, which was the most representative among the arboreal species, the following trees were also recorded: Vernonanthura diffusa (Less.) H. Rob.; Cecropia hololeuca Miq; Vernonanthura phosphor- ica (Vell.) H. Rob.; Senna multijuga (Rich.) H.S. Irwin \& Barneby; Solanum mauritianum Scop and Euterpe edulis Mart.

However, in F2, the most abundant species were: Solanum americanum Mill. (861), Amaranthus deflexus (634), Phyllanthus tenellus (554), Vernonanthura diffusa (340) and Gnaphalium purpureum L. (328). The tree species that occurred in this area were: Vernonanthura phosphorica (111), Trema micrantha (61), Senna multijuga (4), Eucalyptus sp. (4) and Solanum mauritianum (1). After 7 years, none of the planted species were registered in the seed bank.

In both areas there was the presence of invasive exotic grasses of the genus Urochloa. In all F1 plots, Urochloa decumbens Stapf and Urochloa plantaginea (Link) Hitche were observed and, in F2, the presence of Urochloa decumbens was recorded.

Some species presented broad distribution throughout the plots, whereas some species showed very strict distribution. For example, Cecropia hololeuca and Euterpe edulis were found only in plot 8 of area F1, Cyperus distans L. f. and Indeterminate 1 found only in plot 4 of F1. Commelina diffusa and Leonotis nepetifolia were found in parcels 1, 4, 5 and 6 of area F1. The species Phyllanthus tenellus, Conyza canadensis and Lepidium virginicum were found in both areas and in all plots.

The means species richness and the means abundance in F1 and F2 were compared using Student's t test for independent samples at a 5\% significance level $(\mathrm{p}<0.05)$ (Figure 2). Mean species richness was different between the studied environments $(p=0.0002127)$, with greater mean richness in F1 (27.1) than in F2 (21.1). The same behavior was observed regarding abundance of individuals $(p=0.01708)$, with mean of 828.0 propagules in $F 1$ and 417.2 propagules in $F 2$.

In order to identify and evaluate patterns of establishment of the seed banks in both areas, the dendrogram shown in Figure 3 was generated, based on the presence and absence of species and the use of SJ and UPGMA. The Jaccard index between F1 and F2 was 0.61, indicating a high similarity between the analyzed forests, as presented by Kent \& Coker ${ }^{[31]}$. The dendrogram shown demonstrates a grouping tendency of tree species with zoochoric dispersion and also herbaceous species of initial successional categories with anemochoric dispersion.

The classification in successional classes showed the predominance of pioneer $(\mathrm{P})$ species $(\mathrm{F} 1=68.63 \%$; F2 $=71.43 \%)$, as well as individuals $(\mathrm{F} 1=62.86 \% ; \mathrm{F} 2=$ $64.24 \%$ ) in both areas (Figure 4-A), followed by early secondary (ES) species and only a few late secondary (LS) species. 
Table 2. Floristics and phytosociology of the soil seed bank species of the forests undergoing restoration $(\mathrm{F} 1=$ natural regeneration and $\mathrm{F} 2=$ planting of native tree species).

\begin{tabular}{|c|c|c|c|c|c|c|c|c|c|c|c|c|}
\hline Botanical family/species & F1 & NI & $\begin{array}{l}\mathrm{RD} \\
(\%)\end{array}$ & $\begin{array}{l}\text { RF } \\
(\%)\end{array}$ & $\mathrm{F} 2$ & NI & $\begin{array}{l}\text { RD } \\
(\%)\end{array}$ & $\begin{array}{l}\mathrm{RF} \\
(\%)\end{array}$ & OR & LF & $\mathrm{SC}$ & DS \\
\hline \multicolumn{13}{|l|}{ AMARANTHACEAE } \\
\hline Amaranthus deflexus L. & $\cdot$ & 858 & 10.36 & 2.95 & $\cdot$ & 634 & 15.2 & 4.27 & $\mathrm{E}$ & $\mathrm{H}$ & $\mathrm{P}$ & Zoo \\
\hline \multicolumn{13}{|l|}{ ARECACEAE } \\
\hline Euterpe edulis Mart. & $\cdot$ & 4 & 0.05 & 0.37 & & & & & $\mathrm{~N}$ & $\mathrm{~T}$ & LS & Zoo \\
\hline \multicolumn{13}{|l|}{ ASTERACEAE } \\
\hline Ageratum conyzoides L. & $\cdot$ & 1216 & 14.69 & 3.69 & $\cdot$ & 15 & 0.36 & 2.84 & $\mathrm{~N}$ & $\mathrm{H}$ & $P$ & Zoo \\
\hline Baccharis trimera (Less.) DC. & & & & & - & 4 & 0.1 & 1.42 & $\mathrm{~N}$ & $\mathrm{H}$ & $P$ & Ane \\
\hline Conyza canadensis (L.) Cronquist & $\cdot$ & 213 & 2.57 & 3.69 & • & 121 & 2.9 & 4.74 & $\mathrm{E}$ & $\mathrm{H}$ & $\mathrm{P}$ & Ane \\
\hline Emilia sonchifolia (L.) DC. & $\cdot$ & 9 & 0.11 & 1.11 & $\cdot$ & 8 & 0.19 & 1.42 & $\mathrm{~N}$ & $\mathrm{H}$ & $\mathrm{Nc}$ & Ane \\
\hline Erechtites hieraciifolius (L.) Raf. ex DC. & $\cdot$ & 4 & 0.05 & 1.11 & $\cdot$ & 20 & 0.48 & 4.27 & $\mathrm{~N}$ & $\mathrm{H}$ & $\mathrm{P}$ & Ane \\
\hline Erechtites valerianaefolia C.E.C. Fisch. & & & & & • & 8 & 0.19 & 1.42 & $\mathrm{~N}$ & $\mathrm{H}$ & $P$ & Ane \\
\hline Galinsoga parviflora Cav. & • & 63 & 0.76 & 3.32 & $\cdot$ & 3 & 0.07 & 0.95 & $\mathrm{E}$ & $\mathrm{H}$ & $P$ & Ane \\
\hline Galinsoga quadriradiata Ruiz \& Pav. & $\cdot$ & 15 & 0.18 & 0.74 & & & & & $\mathrm{E}$ & $\mathrm{H}$ & $P$ & Ane \\
\hline Gnaphalium pensylvanicum Willd & $\cdot$ & 20 & 0.24 & 2.21 & $\cdot$ & 13 & 0.31 & 2.37 & $\mathrm{~N}$ & $\mathrm{H}$ & ES & Ane \\
\hline Gnaphalium purpureum L. & $\cdot$ & 51 & 0.62 & 1.85 & $\cdot$ & 328 & 7.86 & 4.27 & $\mathrm{~N}$ & $\mathrm{H}$ & ES & Ane \\
\hline Gnaphalium spicatum Mill. & - & 22 & 0.27 & 1.85 & - & 49 & 1.17 & 4.27 & $\mathrm{~N}$ & $\mathrm{H}$ & ES & Ane \\
\hline Sonchus oleraceus L. & $\cdot$ & 8 & 0.1 & 1.11 & $\cdot$ & 20 & 0.48 & 2.84 & $\mathrm{~N}$ & $\mathrm{H}$ & $P$ & Ane \\
\hline Vernonanthura diffusa (Less.) H. Rob. & $\cdot$ & 114 & 1.38 & 3.32 & $\cdot$ & 340 & 8.15 & 4.74 & $\mathrm{~N}$ & $\mathrm{~T}$ & $P$ & Ane \\
\hline Vernonanthura phosphorica (Vell.) H. Rob. & $\cdot$ & 26 & 0.31 & 1.11 & $\cdot$ & 111 & 2.66 & 4.74 & $\mathrm{~N}$ & $\mathrm{~T}$ & $P$ & Ane \\
\hline \multicolumn{13}{|l|}{ BEGONIACEAE } \\
\hline \multicolumn{13}{|l|}{ BRASSICACEAE } \\
\hline \multicolumn{13}{|l|}{ CANNABACEAE } \\
\hline Trema micrantha (L.) Blume & $\cdot$ & 397 & 4.79 & 2.58 & $\cdot$ & 61 & 1.46 & 4.27 & $\mathrm{~N}$ & $\mathrm{~T}$ & $\mathrm{P}$ & Zoo \\
\hline \multicolumn{13}{|l|}{ COMMELINACEAE } \\
\hline Commelina benghalensis $\mathrm{L}$. & $\cdot$ & 67 & 0.81 & 2.21 & $\cdot$ & 1 & 0.02 & 0.47 & $\mathrm{~N}$ & $\mathrm{H}$ & $\mathrm{P}$ & Auto \\
\hline Commelina diffusa Burm. f. & • & 17 & 0.21 & 1.48 & & & & & $\mathrm{~N}$ & $\mathrm{H}$ & $\mathrm{P}$ & Auto \\
\hline \multicolumn{13}{|l|}{ CONVOLVULACEAE } \\
\hline $\begin{array}{c}\text { Ipomoea } \mathrm{sp} . \\
\text { CYPERACEAE }\end{array}$ & \multicolumn{11}{|c|}{ CYPERACEAE } & Ane \\
\hline Cyperus distans L. f. & $\cdot$ & 3 & 0.04 & 0.37 & & & & & $\mathrm{~N}$ & $\mathrm{H}$ & $P$ & Ane \\
\hline $\begin{array}{l}\text { Cyperus rotundus L. } \\
\text { EUPHORBIACEAE }\end{array}$ & \multicolumn{12}{|c|}{ EUPHORBIACEAE } \\
\hline \multicolumn{13}{|l|}{ FABACEAE } \\
\hline Senna multijuga (Rich.) HSIrwin \& Barneby & • & 18 & 0.22 & 2.58 & $\cdot$ & 4 & 0.1 & 0.47 & $\mathrm{~N}$ & $\mathrm{~T}$ & ES & Auto \\
\hline \multicolumn{13}{|l|}{ INDETERMINATE } \\
\hline Indeterminate 1 & $\cdot$ & 15 & 0.18 & 0.37 & & & & & $\mathrm{Nc}$ & $\mathrm{Nc}$ & $\mathrm{Nc}$ & $\mathrm{Nc}$ \\
\hline
\end{tabular}


Indeterminate 2

Indeterminate 3

Indeterminate 4

\section{LAMIACEAE}

Hyptis suaveolens (L.) Poit.

Leonotis nepetifolia (L.) R. Br.

MALVACEAE

Sida rhombifolia $\mathrm{L}$.

Triumfetta rhomboidea Jacq.

MELASTOMATACEAE

Leandra niangaeformis Cogn.

MYRTACEAE

Eucalyptus sp.

ONAGRACEAE

Ludwigia tomentosa (Cambess.) H. Hara

\section{OXALIDACEAE}

Oxalis corniculata $\mathrm{L}$.

\section{PHYLLANTHACEAE}

Phyllanthus tenellus Roxb.

\section{POACEAE}

Digitaria horizontalis Willd.

Digitaria insularis (L.) Fedde

Digitaria sanguinalis (L.) Scop.

Eleusine indica (L.) Gaertn.

Urochloa decumbens Stapf

Urochloa plantaginea (Link) Hitchc.

\section{PORTULACACEAE}

Portulaca oleracea L.

\section{ROSACEAE}

Rubus rosifolius $\mathrm{Sm}$.

\section{RUBIACEAE}

Diodella teres (Walter) Small

Richardia brasiliensis Gomes

Spermacoce latifolia Aubl.

\section{SOLANACEAE}

Nicandra physalodes (L.) Gaertn.

Solanum americanum Mill.

Solanum mauritianum Scop

Solanum sp.

\section{URTICACEAE}

Cecropia hololeuca Miq.

Pilea microphylla (L.) Liebm.

$$
\begin{array}{llll}
\text { - } & 2 & 0.02 & 0.74 \\
\text { - } & 2 & 0.02 & 0.37
\end{array}
$$

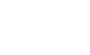$$
\begin{array}{llllllllllll}
\text { - } & 123 & 1.49 & 3.69 & \bullet & 1 & 0.02 & 0.47 & \mathrm{~N} & \mathrm{H} & \mathrm{P} & \text { Zoo } \\
\text { - } & 142 & 1.71 & 1.48 & & & & & \mathrm{E} & \mathrm{S} & \mathrm{P} & \text { Ane }
\end{array}
$$$$
\begin{array}{llllllllllllll}
\text { - } & 272 & 3.29 & 3.69 & - & 105 & 2.52 & 3.32 & \mathrm{~N} & \mathrm{H} & \mathrm{P} & \text { Ane }
\end{array}
$$$$
\begin{array}{llllllllllll}
\text { - } & 12 & 0.14 & 1.11 & \bullet & 6 & 0.14 & 0.95 & \mathrm{E} & \mathrm{S} & \mathrm{P} & \text { Zoo }
\end{array}
$$$$
\begin{array}{llllllllllll}
42 & 0.51 & 2.58 & \bullet & 57 & 1.37 & 2.84 & \mathrm{~N} & \mathrm{~S} & \mathrm{P} & \text { Zoo }
\end{array}
$$

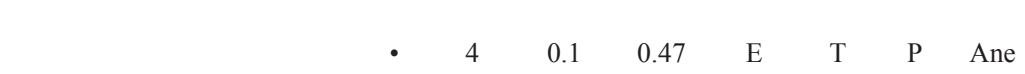$$
\begin{array}{lll}
\text { - } \quad 49 & 0.59 \quad 2.21
\end{array}
$$$$
\mathrm{N} \quad \mathrm{S} \quad \mathrm{P} \text { Ane }
$$$$
\begin{array}{llllllllllll}
\text { - } & 691 & 8.35 & 3.69 & \bullet & 167 & 4 & 3.79 & \mathrm{E} & \mathrm{H} & \mathrm{Nc} & \text { Ane }
\end{array}
$$

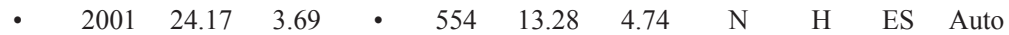$$
\begin{array}{lllllllllllll}
- & 179 & 2.16 & 3.69 & \bullet & 10 & 0.24 & 0.95 & \mathrm{~N} & \mathrm{H} & \mathrm{P} & \text { Ane }
\end{array}
$$$$
\begin{array}{llllllll}
\text { - } & 69 & 0.83 & 2.21 & \mathrm{~N} & \mathrm{H} & \mathrm{P} & \text { Ane }
\end{array}
$$$$
\begin{array}{lllllllllllll}
\text { - } & 35 & 0.42 & 2.95 & \text { - } & 4 & 0.1 & 0.47 & \mathrm{~N} & \mathrm{H} & \mathrm{P} & \text { Ane }
\end{array}
$$

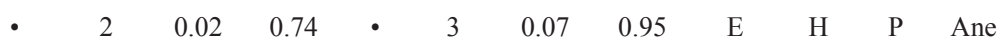

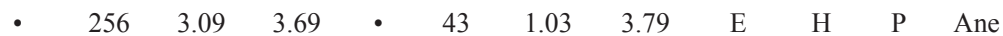$$
\begin{array}{llllllll}
\text { - } & 13 & 0.16 & 1.11 & \text { E } & \text { H } & \text { P Ane }
\end{array}
$$$$
\begin{array}{lllllllllll}
- & 2 & 0.02 & 0.37 & 31 & 0.74 & 0.47 & \mathrm{~N} & \mathrm{H} & \mathrm{Nc} & \mathrm{Zoo}
\end{array}
$$$$
\begin{array}{lllllllllll}
\text { - } & 87 & 1.05 & 1.85 & 300 & 7.19 & 3.79 & \mathrm{~N} & \mathrm{~S} & \mathrm{LS} & \text { Zoo }
\end{array}
$$$$
\begin{array}{llllllllllllllll}
- & 15 & 0.18 & 1.85 & - & 3 & 0.07 & 0.47 & \mathrm{~N} & \mathrm{H} & \mathrm{P} & \mathrm{Nc}
\end{array}
$$$$
\begin{array}{llllllllllll}
- & 141 & 1.7 & 3.32 & \bullet & 24 & 0.58 & 3.79 & \mathrm{~N} & \mathrm{H} & \mathrm{Nc} & \text { Ane }
\end{array}
$$$$
\begin{array}{llllllllllll}
\text { - } & 5 & 0.06 & 0.37 & \bullet & 11 & 0.26 & 1.42 & \mathrm{~N} & \mathrm{H} & \mathrm{ES} & \text { Auto }
\end{array}
$$$$
\begin{array}{llllllll}
\text { - } & 5 & 0.06 & 0.37 & \mathrm{E} & \mathrm{H} & \mathrm{Nc} & \mathrm{Zoo}
\end{array}
$$$$
\begin{array}{llllllllllll}
- & 250 & 3.02 & 3.69 & \bullet & 861 & 20.64 & 3.79 & \mathrm{~N} & \mathrm{H} & \mathrm{P} & \text { Zoo }
\end{array}
$$$$
\begin{array}{lllllllllllll}
- & 6 & 0.07 & 0.37 & \bullet & 1 & 0.02 & 0.47 & \mathrm{~N} & \mathrm{~T} & \mathrm{P} & \text { Zoo }
\end{array}
$$$$
\begin{array}{llllllllll}
- & 5 & 0.12 & 0.47 & \mathrm{~N} & \mathrm{H} & \mathrm{P} & \mathrm{Zoo}
\end{array}
$$

$$
\text { TOTAL }
$$

NI: Number of individuals; RD: Relative density; RF: Relative frequency; OR: Origin (N= Native, E= Exotic); LF: Life Form; $(T=$ Tree, $S=$ Shrub, $H=H e r b, V=V i n e) ; S C$ : Successional category $(P=$ Pioneer, $E S=$ Early secondary, $L S=$ Late secondary); DS: Dispersal syndrome (Ane= anemochory; Zoo= zoochory; Auto= autochory); Nc: Not Classified; $\because$ Indicates de presence of the species in the soil seed bank 
(a)

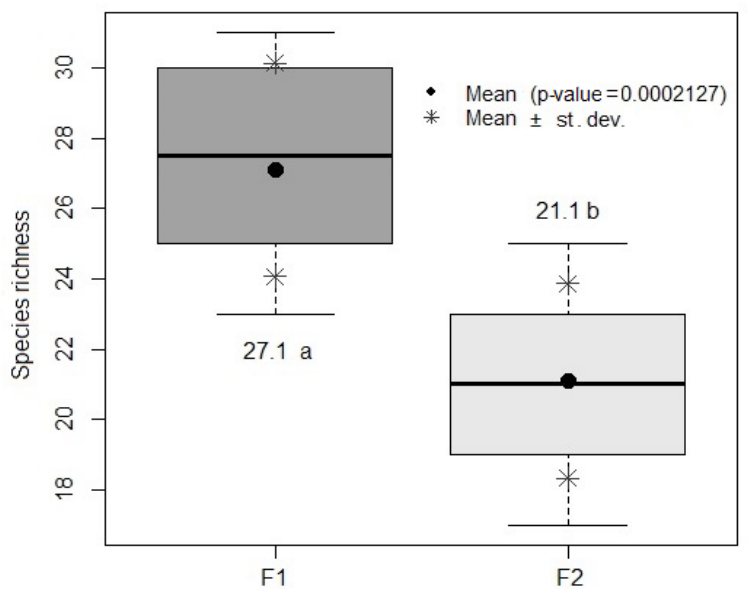

(b)

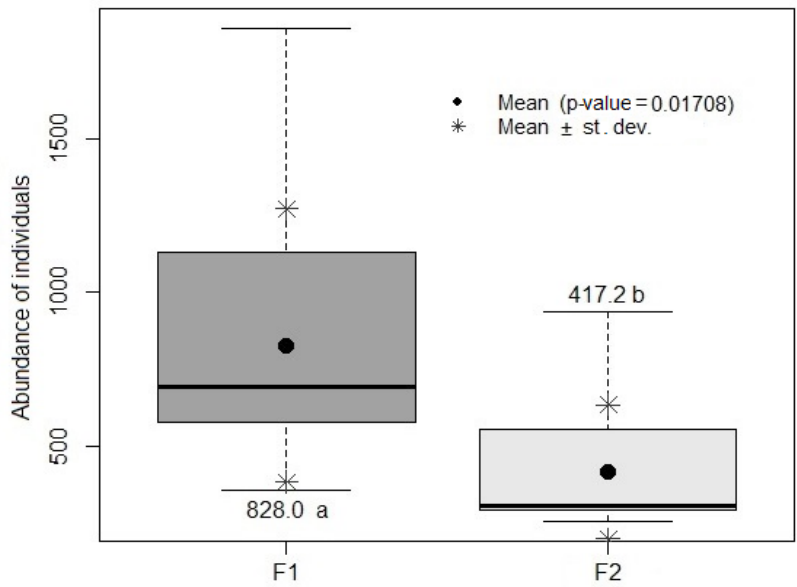

Figure 2. Boxplot of a) species richness and b) abundance of individuals. Numbers followed by different letters are statistically different $\mathrm{p} \leq 0.05$ (Student's $\mathrm{t}$ test). ( $\mathrm{F} 1=$ natural regeneration, $\mathrm{F} 2=$ planting of native tree species and st. dev. $=$ standard deviation).

\section{Cluster Dendrogram (UPGMA)}

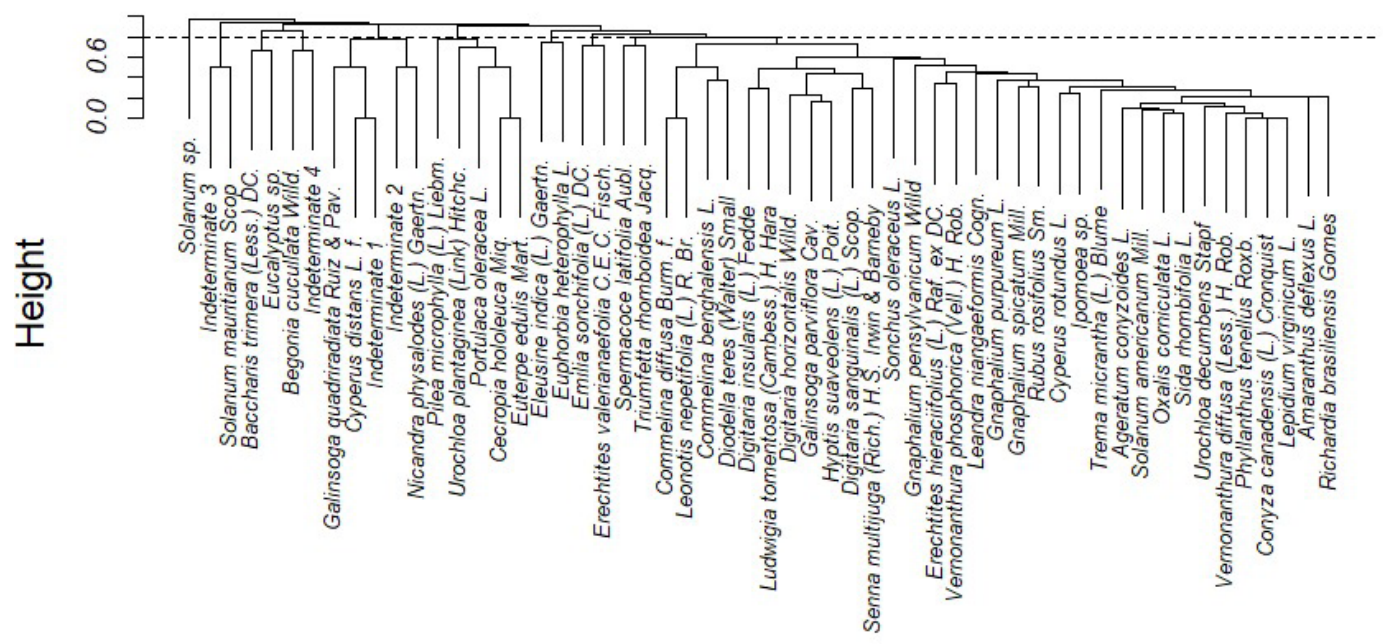

Jaccard

hclust (* "average")

Figure 3. Dendrogram of similarity between the different species found of the soil seed bank of the forests undergoing restoration $(\mathrm{F} 1=$ natural regeneration and $\mathrm{F} 2=$ planting of native tree species). The dendrogram was produced using the UPGMA (Unweighted Pair Group Method with Arithmetic Mean) clustering method based on the Jaccard similarity index.

Regarding the dispersal syndrome classification, anemochoric (Ane) species predominated in both areas $(\mathrm{F} 1=52.94 \% ; \mathrm{F} 2=57.14 \%)$. However, most individuals showed dispersion by animals $(\mathrm{F} 1=36.03 \%$; F2 $=$ $35.02 \%$ ) (Figure 4-B).

In both $\mathrm{F} 1$ and $\mathrm{F} 2$, herbaceous $(\mathrm{H})$ species and individuals predominated (Figure 4-C). Moreover, 7 tree species were registered in F1 and 6 species were registered in F2, including the exotic Eucalyptus sp. The number of tree individuals was higher in F1 (613) than in F2 (521), mainly due to the contribution of the species Trema micrantha.

There was a predominance of native species and individuals in both areas ( $F 1=70,59 \% ; F 2=76,19 \%)$. The proportion of native $(\mathrm{N})$ and exotic (E) individuals was similar between $\mathrm{F} 1$ and $\mathrm{F} 2$, although the number of exotic species and individuals was slightly higher in F1 (Figure 


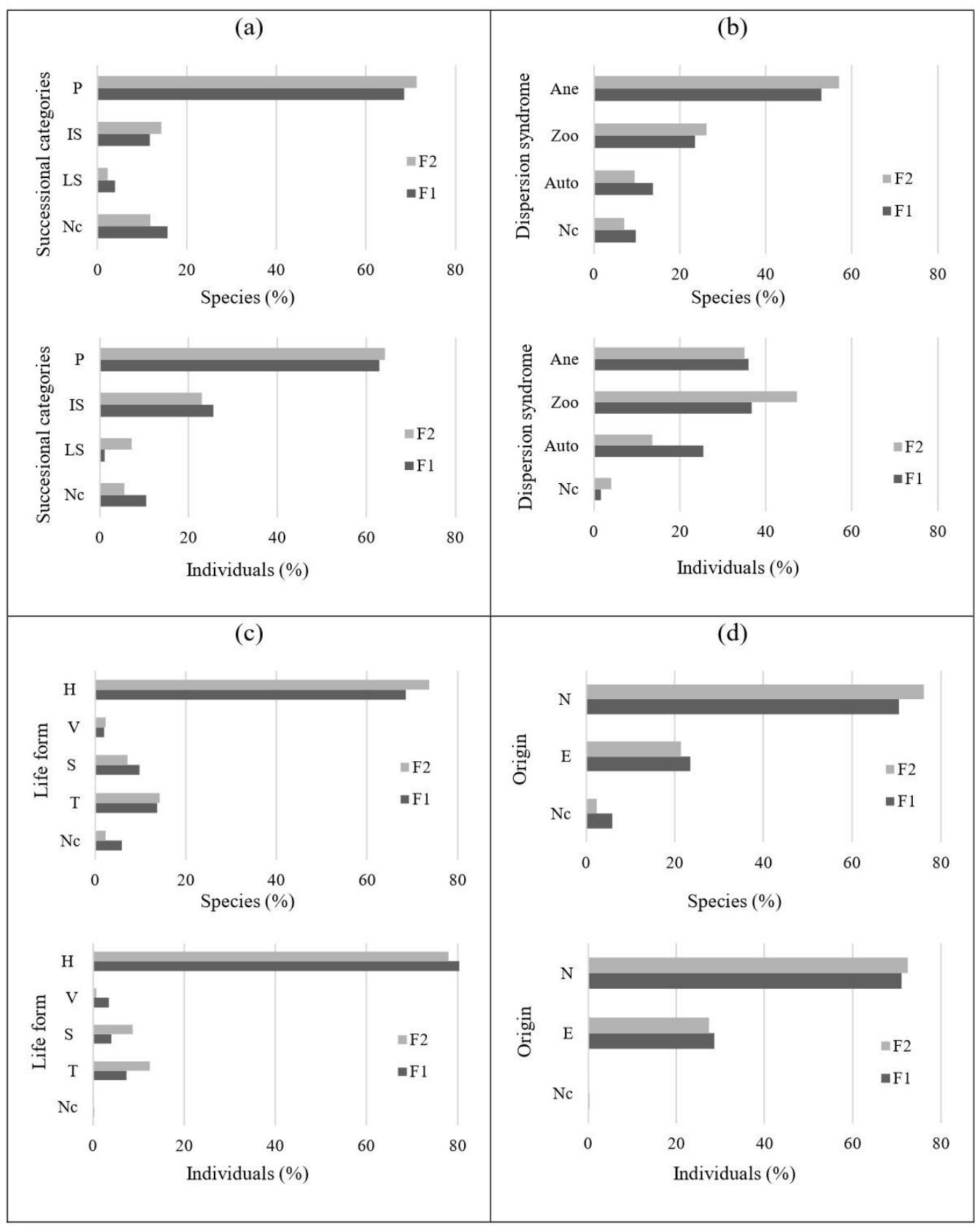

Figure 4. Distribution of emerged species and individuals of the soil seed bank species of the forests undergoing restoration $(\mathrm{F} 1=$ natural regeneration and $\mathrm{F} 2=$ planting of native tree species) classified in (a) successional categories ( $\mathrm{P}$ : pioneer; IS: initial secondary; LS: late secondary), in (b) dispersion syndrome (Ane: anemochory; Auto: autochory; Zoo: zoochory); in (c) Life form (T: tree; S: shrub; H: herb; V: vine) and (d) origin (N: native, E: exotic). Nc: not classified.

Regarding the dispersal syndrome classification, anemochoric (Ane) species predominated in both areas $(\mathrm{F} 1=52.94 \% ; \mathrm{F} 2=57.14 \%)$. However, most individuals showed dispersion by animals $(\mathrm{F} 1=36.03 \%$; F2 = $35.02 \%$ ) (Figure 4-B).

In both $\mathrm{F} 1$ and $\mathrm{F} 2$, herbaceous $(\mathrm{H})$ species and individuals predominated (Figure 4-C). Moreover, 7 tree species were registered in F1 and 6 species were registered in F2, including the exotic Eucalyptus sp. The number of tree individuals was higher in F1 (613) than in F2 (521), mainly due to the contribution of the species Trema micrantha.

There was a predominance of native species and individuals in both areas $(\mathrm{F} 1=70,59 \% ; \mathrm{F} 2=76,19 \%)$. The proportion of native $(\mathrm{N})$ and exotic $(\mathrm{E})$ individuals was similar between F1 and F2, although the number of exotic species and individuals was slightly higher in F1 (Figure 4-D). 


\section{Discussion}

The soil seed bank in areas at an early stage of succession tends to have a high density of seeds, decreasing as the succession progresses ${ }^{[32]}$. In F1, the density of propagules found $\left(2,114.94 \mathrm{~m}^{-2}\right)$ is higher than the average density indicated by Garwood ${ }^{[1]}$ in secondary tropical forests $\left(1,650\right.$ propagules $\left.\mathrm{m}^{-2}\right)$, which is justified due to the greater presence of pioneer species in the topsoil, whose seeds have dormancy and tend to remain viable in the soil for a longer period.

In $\mathrm{F} 2$, the density of $1,168.62$ propagules $\mathrm{m}^{-2}$ corroborates the study by Miranda Neto ${ }^{[33]}$, in which 830 propagules $\mathrm{m}^{-2}$ were found in an area with ten years of restoration. This lower density of propagules, compared to F1, reveals that the area may be under greater influence from eucalyptus planting, which in turn acts as a barrier, reducing wind speed and consequently limiting anemochoric dispersal.

These variations in the density of soil seeds in different areas can be related to several factors such as the type of disturbance, history of the area, the presence and quantity of dispersers and geographical barriers ${ }^{[34]}$. As observed, most of the species and individuals sampled in the seed bank are herbaceous (F1 and F2), which is common in this type of study, as noted by Balestrin et al. ${ }^{[20]}$, Costalonga ${ }^{[35]}$, Martins ${ }^{[36]}$ and Silva et al. ${ }^{[37]}$ as a characteristic of disturbed environments. In addition, the predominance of this life form can be explained by the life cycle of these species, high seed production and history of agricultural use in the area (pasture and coffee plantation), among other factors.

It should also be noted that these herbaceous species are fundamental in the early stages of ecological succession, as they present a high potential to colonize altered environments ${ }^{[38,39]}$. Because they usually have facultative dormancy and efficient dispersion mechanisms, this group of species presents a better adaptation in disturbed areas, in addition to improving soil conditions, both in water retention and in the formation of aggregates, avoiding erosion processes. These improvements in edaphic conditions help the development of pioneer shrub and tree species, and as the succession process increases, there is a tendency to decrease the density of herbaceous species in the soil seed bank ${ }^{[13,40]}$.

In F1, the Phyllanthaceae family, with only one species (Phyllanthus tenellus), presented the highest relative density $(24.17 \%)$ due to the fact that it was the species with the largest number of individuals in the seed bank, followed by the Asteraceae family (21.27\%), as also verified by Miranda Neto et al. ${ }^{[33]}$ and Oliveira et al. ${ }^{[4]]}$. In F2, the
Asteraceae (24.93\%) and Solanaceae (20.78\%) families had the highest relative densities, as well as in surveys carried out in tropical forests in the Atlantic Forest domain [34,37,40].

The greater richness of species in the Asteraceae family and the high number of individuals contributed to the high density of this family in both areas. This can be explained by the predominance of species of herbaceous life forms and anemochory dispersion syndrome, which have a survival strategy based on a rapid life cycle and abundant seed production, which are easily dispersed by the wind ${ }^{[11]}$. Due to this behavior, this family is already consolidated as the most important in several seed bank studies ${ }^{[34,37]}$.

Moreover, due to the age of planting (only 7 years) and the predominance of final species of succession in area F2, it is likely that the species are not fruiting and depositing seeds in the bank, therefore they were not recorded in the evaluation, confirming studies carried out in the region and in mining environments, as reported by Miranda Neto et al. ${ }^{[33]}$. This result corroborates with the idea that the age of the first reproduction varies according to the successional class, usually in the pioneers it occurs prematurely (1-5 years); in early secondary (5-10 years) and late secondary ( $>10$ years) ${ }^{[42]}$.

The highest proportion of pioneer species and individuals, in both areas under restoration (F1 and F2), confirms data from other studies on soil seed banks in Minas Gerais $[3,35,37,43]$ and in other forest formations in Brazil ${ }^{[44]}$. Thus, the predominance of native pioneer species in the seed bank is due to the ability to form a persistent bank in the soil due to long seed viability, high seed production, efficient dispersion mechanisms and because they normally show fast growth at full sun, being an excellent indicator of resilience to natural or man-made disturbances ${ }^{[32]}$.

In this sense, the predominance of pioneer and native species on the soil seed bank strengthens the potential for vegetation recovery, in case of severe disturbances ${ }^{[44]}$. However, continuous monitoring of the area is necessary to prevent the high number of seeds of exotic species present in the soil from germinating and invading the area, which can hinder the establishment of native species and hinder the successional advance ${ }^{[7,20]}$.

The greater richness of species with anemochoric dispersion found in both areas, corroborates that verified by Guimarães et al. ${ }^{[45]}$, which demonstrates the predominance of this category in studies on seed banks in areas under restoration in the phytophysiognomy Seasonal Semideciduous Forest, in the Atlantic Forest domain and also in studies in areas of forest undergoing restoration after bauxite mining ${ }^{[33,37]}$.

In terms of individuals, the predominance of zoochoric 
dispersion in F1 and in F2, reveals the importance of forest fragments as a source of resource and shelter for the maintenance of propagating dispersal fauna, especially in the beginning of forest regeneration after disturbances ${ }^{[34]}$, contributing to the enrichment of the seed bank and seedling bank of forests under restoration.

In F1, the presence of Euterpe edulis stands out, a zoochoric tree species that has a high fruit production and great reproduction capacity, which are very attractive to wild fauna ${ }^{[46]}$. It is considered a key species in the ecosystem, mainly for the restoration of impacted areas, being present in the Red Book of Flora of Brazil, in the "Vulnerable" (VU) category ${ }^{[47]}$.

The high representativeness of Trema micranta has also been observed by other authors in areas that have suffered some disturbances ${ }^{[33,36,48]}$. It is a nucleating species, a pioneer with rapid growth in adverse conditions and which has a reproductive strategy based on the early and continuous production of orthodox seeds, mainly dispersed by frugivorous birds. In addition, efficient dormancy mechanisms ensure high seed longevity ${ }^{[36,49]}$.

Also, due to the morphometric characteristics of the canopy (wide and dense), T. micrantha can be indicated as a species of the filling group in ecological restoration plantations, with the function of live perch and also to prevent invasion of aggressive grasses, through the rapid shading of the soil. Thus, the species plays a fundamental role in the resilience of ecosystems and is considered one of the main alternatives to enable the restoration of mined areas ${ }^{[36]}$.

The Shannon diversity index $\left(\mathrm{F} 1: \mathrm{H}^{\prime}=2.770\right.$ and F2: $\mathrm{H}^{\prime}=2.618$ ) indicates good diversity in both areas, while the Pielou's equability ( $\mathrm{F} 1: \mathrm{J}{ }^{\mathrm{c}}=0.705$ and $\left.\mathrm{F} 2: \mathrm{J}{ }^{\mathrm{c}}=0.700\right)$ indicates floristic heterogeneity, i.e., absence of ecological dominance, in accordance with the study by Miranda Neto et $\mathrm{al}^{[50]}$ in the same region and in mining environments. In addition, the results were superior to those found in the studies by Costalonga ${ }^{[35]}$, Braga, et al. ${ }^{[43]}$ and Miranda Neto et al ${ }^{[48]}$ carried out in Semideciduous Seasonal Forest in different situations and stages of development.

In contrast, in the same forest typology as the study areas, higher values of diversity were observed in the studies by Miranda Neto et al. ${ }^{[50]}$ and Peres et al. ${ }^{[51]}$. Such variations in the diversity indexes may be related to the successional characteristics of the area, landscape features, as well as the occurrence of impacts and changes in these areas. In this sense, these results corroborate the idea that the proximity to preserved forest fragments facilitates the continuity of the gene flow between communities, and consequently help the restoration of areas ${ }^{[20,52,53,54]}$.

The high similarity according to the Jaccard index (SJ) indicates a certain degree of species shared between the seed banks in the two areas. This similarity may be related to the geographical proximity of the areas and, consequently, to be influenced by seed rain. Other determining factors in this result are the origin of the topsoil used (taken from the same areas) and also the role of the dispersing fauna, since both in F1 and in F2 most individuals are zoochoric, which enhances resource availability and spatial reach for these animals, contributing to the observed similarity.

Through the similarity dendrogram, it is possible to observe the grouping of some tree species that have zoochoric dispersion, such as Euterpe edulis and Cecropia hololeuca, present in $\mathrm{F} 1$. This is because many zoochoric species may be being dispersed mainly under nests or along routes used by birds and frugivorous animals ${ }^{[55]}$.

It was also observed the spatial grouping of species $C y$ perus distans L. f. and Indeterminate 1 found only in parcel 4 of F1, and there may be some restrictive site characteristics, such as edaphic conditions or luminosity, which justify this condition ${ }^{[20]}$. This characteristic can also be verified through the grouping of the species Commelina diffusa Burm. f. and Leonotis nepetifolia (L.) R. Br., present exclusively in F1, in parcels 1, 4, 5 and 6.

In addition, there was a trend towards the spatial grouping of pioneer herbaceous species, such as Conyza canadensis (L.) Cronquist, Lepidium virginicum L., and the initial secondary Phyllanthus tenellus. This result collaborates with the idea that species of initial successional groups tend to remain dormant in the seed bank, waiting for ideal conditions to germinate (light, humidity, temperature, etc.), which facilitates the recovery of these environments in case of any disturbance (eg.: clearings formed by falling or cutting trees). In this way, such seeds, generally positive photoblastic, are able to germinate and thus promote rapid vegetation cover ${ }^{[56]}$.

In this sense, these species have a fundamental role in nature and in the restoration process, as they have a high capacity for adaptation in disturbed environments, generally have a high power of dissemination, in addition to developing under different conditions of light and humidity, thus facilitating the emergence of more advanced and more demanding species from the nutritional point of view, in addition to enabling their use in restoration projects ${ }^{[12]}$.

The presence of Urochloa decumbens in all F1 plots reveals the need for constant monitoring of the area, in order to control possible clearings that favor the development and colonization of these species. In F2, Urochloa decumbens was also found, although with less frequency. These results are explained by the topsoil origin, since 
before mining the areas were used for agricultural crops and pasture, and specially by the current proximity to pasture areas, which demonstrates the influence of the spatial variable on the dissemination and development of plant species, especially with regard to invasive grass species.

\section{Conclusions}

The soil seed banks of the two studied areas are relatively similar floristically and functionally. This indicates that both natural regeneration and reforestation were efficient in the ecological restoration. However, species richness and abundance were greater in the forest in natural regeneration, highlighting this technique as an alternative for restoring these environments, as long as they are inserted in a landscape with remnants of preserved native forests and that receive actions to recover and conserve the mined soil as topographic reconformation, topsoil transposition, and soil preparation, as made by the mining company.

\section{Acknowledgments}

To the CNPq, Fapemig and Capes by research fellowships for the authors and to the Companhia Brasileira de Alumínio for provided infrastructure and financial support for the project.

\section{References}

[1] ANM. Brazilian Mineral Summary - Aluminum. 1 st ed. Brasília: Agência Nacional de Mineração [R]. 2018, 4. (in Portuguese)

[2] ANM. Brazilian Mineral Yearbook - Main Metallic Commodities 2018. 1 st ed. Brasília: Agência Nacional de Mineração [R]. 2019, 34. (in Portuguese)

[3] Barros DA, Guimarães JCC, Pereira JAA, Borges LAC, Silva RA, Pereira AAS. Characterization of the bauxite mining of the Poços de Caldas alkaline massif and its socio-environmental impacts. Revista Escola de Minas [J]. 2012, 65(1):127-133. DOI: doi.org/10.1590/S0370-44672012000100018

[4] Fengler FH, Bressane A, Carvalho MM, Longo RM, Medeiros GA, Melo WJ, Jakovac CC, Ribeiro AI. Forest restoration assessment in Brazilian Amazonia: A new clustering-based methodology considering the reference ecosystem. Ecological Engineering [J]. 2017, 108(1):93-99.

DOI: doi.org/10.1016/j.ecoleng.2017.08.008

[5] Martins SV. Alternative Forest Restoration Techniques. In: Viana H, (ed.). New Perspectives in Forest Science. 1st ed. London: IntechOpen [C]. 2018: 131-148.
DOI: 10.5772 / intechopen.72908

[6] Bastin JF, Finegold Y, García C, Mollicone D, Rezende M, Routh D, Zohner CM, Crowther TW. The global tree restoration potential. Science $[\mathrm{J}]$. 2019, 365(6448):76-79.

DOI: $10.1126 /$ science.aax 0848

[7] Brancalion PHS, Viani RAG, Rodrigues RR, Gandolfi S. Evaluation and monitoring of areas under restoration. In: Martins SV (ed). Ecological restoration of degraded ecosystems, 2 nd ed. Editora UFV [C]. 2015: 262-292. (in Portuguese)

[8] Balestrin D, Martins SV, Schoorl JM, Lopes AT, Andrade CF. Phytosociological study to define restoration measures in a mined area in Minas Gerais, Brazil. Ecological Engineering [J]. 2019, 135(10): 8-16.

DOI: doi.org/10.1016/j.ecoleng.2019.04.023

[9] Martins SV. Recovery of degraded areas: actions in permanent preservation areas, gullies, road slopes and mining. 4rd ed. Viçosa: Aprenda Fácil [M]. 2016: 270. (in Portuguese)

[10] Harper JL. Population biology of plants. London: Academic Press [M]. 1977: 924

[11] Garwood N. C. Tropical soil seed banks: a review. In: Leck MA, Parker VT, Simpson RL (eds). Ecology of soil seed banks. 1st ed. San Diego: Academic Press [C]. 1989, 149-209.

DOI: doi.org/10.1016/b978-0-12-440405-2.50014-2

[12] Martins SV, Borges EEL, Silva KA. The soil seed bank and its use as a bioindicator of ecological restoration. In: Martins SV (ed.). Ecological restoration of degraded ecosystems. 2nd ed. Viçosa: Editora UFV [C]. 2015: 293-330. (in Portuguese)

[13] Calegari L, Martins SV, Campos LC, Silva E, Gleriani JM. Evaluation of the soil seed bank for forest restoration purposes in Carandaí, MG. Revista Arvore [J]. 2013, 37(5):871-880. (in Portuguese) DOI: doi.org/10.1590/S0100-67622013000500009

[14] Madawala H, Ekanayake SK, Perera G. Diversity, composition and richness of soil seed banks in different forest communities at Dotalugala Man and Biosphere Reserve, Sri Lanka. Ceylon Journal of Science [J]. 2016, 45(1):43-55.

DOI: 10.4038 / cjs.v45i1.7363

[15] Rozendaal DMA, Bongers F, Aide TM, Alvarez-Dávila E, Ascarrunz N, Balvanera P, Becknell JM, Bentos TV, Brancalion PHS, Cabral GLA et al. Biodiversity recovery of Neotropical secondary forests. Science Advances [J]. 2019, 5(3):eaau3114. DOI: 10.1126 / sciadv.aau3114

[16] Köppen W. Climatology: A study of the Earth's climates. México: Fondo de Cultura Econômica [M] 
1948: 477. (in Spanish)

[17] Agevap. 2013. Municipal basic sanitation plan, São Sebastião da Vargem Alegre, MG [R]. PrintPaper Editora Gráfica, 2013: 234. (in Portuguese)

[18] Santos HG, Jacomine PKT, Anjos LHC, Oliveira VA, Lumbreras JF, Coelho MR, Almeida JA, Araujo Filho JC, Oliveira JB, Cunha TJF. Brazilian system of soil classification. Brasília: Embrapa [M]. 2018: 356. (in Portuguese)

[19] IBGE. Technical Manual of the Brazilian vegetation. 2nd ed. Technical Manuals in Geosciences. Rio de Janeiro: Instituto Brasileiro de Geografia e Estatística. 2012: 272. (in Portuguese)

[20] Balestrin D, Martins SV, Fonseca W, Cosimo LHE. Relationship between soil seed bank and canopy coverage in a mined area. Revista Árvore [J]. 2019, 43(4): 430403.

DOI: doi.org/10.1590/1806-90882019000400003

[21] Angiosperm Phylogeny Group IV. An update of the Angiosperm Phylogeny Group classification for the orders and families of flowering plants. Botanical Journal of the Linnean Society [J]. 2016, 181:1-20.

DOI: doi.org/10.1111/boj.12385

[22] The Plant List. 2018. Version 1.1. [Accessed on 05/02/2018]. http://www.theplantlist.org

[23] Budowski G. Distribution of tropical American Rain Forest species in the light of successional processes. Turrialba [J]. 1965, 15:40-42.

[24] Gandolfi S, Leitão Filho HF, Bezerra CLF. Floristic survey and successional character of shrub-tree species in a semideciduous forest in the city of Guarulhos, SP. Revista Brasileira de Biologia [J]. 1995, 55:753-767. (in Portuguese)

[25] van der Pijl L. Principles of dispersal in higher plants. 3rd ed. Berlin and New York: Springer-Verlag [M]. 1982: 214.

DOI: 10.1007 / 978-3-642-87925-8

[26] Mueller-Dombois D, Ellenberg H. Aims and methods of vegetation ecology. New York: John Wiley \& Sons [M]. 1974: 580.

[27] Magurran AE. Ecological diversity and its measurement. Princeton: Princeton University Press [M]. 1988: 179.

[28] Pielou EC. Ecological diversity. New York: Jonhon Willy [M]. 1975: 176.

[29] Shepherd GJ. Fitopac. Version 2.1. Campinas: Departamento de Botânica, Universidade Estadual de Campinas. 2010.

[30] R Development Core Team. R: A language and environment for statistical computing. Version 3.5.1. Vienna: R Foundation for Statistical Computing. 2018.

[31] Kent M, Coker P. Vegetation description analyses.
London: Belhaven Press [M]. 1992: 428.

[32] Dalling JW. Seed ecology. In: Guariguata MR, Kattan $\mathrm{GH}$, editors. Ecology and conservation of neotropical forests. Cartago: Libro Universitario Regional [C]. 2002: 345-375. (in Spanish)

[33] Miranda Neto A, Martins SV, Silva KA, Lopes AT, Demolinari RA. Soil seed bank in a restored bauxite mine in Southeast Brazil. Floresta e Ambiente [J]. 2017, 24(1):e00125414. (in Portuguese)

DOI: doi.org/10.1590/2179-8087.125414.

[34] Franco BKS, Martins SV, Faria PCL, Ribeiro GA. Density and floristic composition of the seed bank of a stretch of Semideciduous Seasonal Forest on the Campus of the Federal University of Viçosa, Viçosa, MG. Revista Árvore [J]. 2012, 36(3):423-432. (in Portuguese)

DOI: doi.org/10.1590/S0100-67622012000300004.

[35] Costalonga SR, Reis GG, Reis MGF, Silva AF, Borges EEL, Guimarães FP. Floristics of the soil seed bank in contiguous areas of degraded pasture, eucalyptus plantation and forest in Paula Cândido, MG. Floresta [J]. 2006, 36(2):239-250. (in Portuguese) DOI: doi.org/10.5380/rf.v36i2.6455

[36] Martins SV. Soil seed bank as indicator of forest regeneration potential in canopy gaps of a semideciduos forest in southeastern Brazil. In: Fournier MV (ed). Forest regeneration: ecology, management and economics. New York: Nova Science Publishers [C]. 2009, 113-128.

DOI: doi.org/10.1590/S0100-67622008000600013.

[37] Silva KA, Martins SV, Miranda Neto A, Lopes AT. Soil seed banks in a forest under restoration and in a reference ecosystem in Southeastern Brazil. Floresta e Ambiente [J]. 2019, 26 (4):e20190047.

DOI: doi.org/10.1590/2179-8087.004719

[38] Reis A, Bechara, FC, Tres DR, Trentin BE. 2014. Nucleation: Biocentric conception for the ecological restoration. Ciência Florestal [J]. 2014, 24(2):509519.

DOI: doi.org/10.5902/1980509814591

[39] Erfanzadeh R, Shayesteh Palaye AA, Ghelichnia H. Shrub effects on germinable soil seed bank in overgrazed rangelands. Plant Ecology \& Diversity [J]. 2020, 13(2): 199-208.

DOI: doi.org/10.1080/17550874.2020.1718233

[40] Baider C, Tabarelli M, Mantovani W. The soil seed bank during Atlantic forest regeneration in Southeast Brazil. Revista Brasileira de Biologia [J]. 2001, 61(1):35-44.

DOI: doi.org/10.1590/S0034-71082001000100006

[41] Oliveira TJF, Barroso DG, Andrade AG, Freitas ILJ, Amim RT. Soil seed bank for use in the recovery of 
degraded riparian forests in the Northwestern region of Rio de Janeiro State. Ciência Florestal [J]. 2018, 28(1):206-217. (in Portuguese)

DOI: doi.org/10.5902/1980509831653

[42] Ferretti AR, Kageyama PY, Árbocz GF, Santos JD, Barros MIA, Lorza RF, Oliveira C. Classification of tree species in ecological groups for Revegetation with native species in the State of São Paulo. Florestar Estatístico [J]. 1995, 3(7):73-77. (in Portuguese)

[43] Braga AJT, Griffith JJ, Paiva HN, Meira Neto AA. Composition of the soil seed bank of a secondary semideciduous forest considering its potential use for environmental recovery. Revista Árvore [J]. 2008, 32(6):1089-1098. (in Portuguese)

DOI: doi.org/10.1590/S0100-67622008000600014.

[44] Silva-Weber AJC, Nogueira AC, Carpanezzi AA, Galvão F, Weber SH. Floristic composition and seasonal distribution of the soil seed bank in Alluvial Mixed Rain Forest, Araucária, PR. Pesquisa Florestal Brasileira [J]. 2012, 32(70):193-207. (in Portuguese) DOI: 10.4336/2012.pfb.32.70.77

[45] Guimarães S, Martins SV, Neri AV, Gleriani JM, Silva KA. Soil seed bank of areas under forest restoration in Aimorés, MG. Pesquisa Florestal Brasileira [J]. 2014, 34(80):357-368. (in Portuguese)

DOI: doi.org/10.4336/2014.pfb.34.80.437

[46] Galetti M, Bovendorp RS, Guevara R. Defaunation of large mammals leads to an increase in seed predation in the Atlantic forests. Global Ecology and Conservation $[\mathrm{J}] .2015$, 3:824-830.

DOI: doi.org/10.1016/j.gecco.2015.04.008

[47] Martinelli G, Moraes MA. Red book of flora of Brazil. Rio de Janeiro: Andrea Jakobsson [M]. 2013:1100. (in Portuguese)

[48] Miranda Neto A, Martins SV, Silva KA. Soil seed banks in different environments: initial forest, mature forest, Pinus and Eucalyptus abandoned stands. Plant Biosystems [J]. 2020, 154(1):1-8.

DOI: doi.org/10.1080/11263504.2020.1727979

[49] Silveira K, Skillman JB, Dallind JW. Seed germination, seedling growth and habitat partitioning in two morphotypes of the tropical pioneer tree Trema micrantha in a seasonal forest in Panam. Journal of Tropical Ecology [J]. 2003, 19(1):27-34.
DOI: doi.org/10.1017/S0266467403003043

[50] Miranda Neto A, Martins SV, Silva KA, Gleriani JM. Soil seed bank and litter accumulated in restored forest. Revista Árvore [J]. 2014, 38(4):609-620. (in Portuguese)

DOI: https://doi.org/10.1590/S0100-67622014000400004.

[51] Peres MA, Pinto LVA, Loures L. Evaluation of soil seed banks of climatic and secondary seasonal semideciduous forest fragments and their potential to recover degraded areas. Revista Agrogeoambiental [J]. 2009, 1(2):121-133. (in Portuguese)

DOI: doi.org/10.18406/2316-1817v1n2200984

[52] Miranda Neto A, Martins SV, Silva KA, Lopes AT, Demolinari RA. Natural regeneration in a restored bauxite mine in southeast Brazil. Bosque [J]. 2014, 35(3):377-389.

DOI: 10.4067 / S0717-92002014000300012

[53] Crouzeilles R, Ferreira MS, Chazdon RL, Lindenmayer DB, Sansevero JBB, Monteiro L, Iribarrem A, Latawiec AE, Strassburg BBN. Ecological restoration success is higher for natural regeneration than for active restoration in tropical forests. Sciense Advances [J]. 2017, 3(11):e1701345.

DOI: 10.1126 / sciadv.1701345

[54] Rezende GM, Vieira DLM. Forest restoration in southern Amazonia: Soil preparation triggers natural regeneration. Forest Ecology and Management $[\mathrm{J}]$. 2019, 433(3):93-104.

DOI: doi.org/10.1016/j.foreco.2018.10.049

[55] Schupp EW, Milleron T, Russo S. 2002. Dissemination limitation and the origin and maintenance of species-rich tropical forests. In: DJ Levey; WR Silva, M Galleti, editors. Seed Dispersal and Frugivory: Ecology, Evolution and Conservation. New York: CABI Publishing [C]. 2002: 19-33.

[56] Souza RP, Valio IFM. Seed size, seed germination and seedling survival of Brazilian tropical tree species differing in successional status. Biotropica $[\mathrm{J}]$. 2001, 33(3):447-457.

DOI: https://doi.org/10.1111/j.1744-7429.2001. tb00198.x 